\title{
Article/Artigo
}

\section{Phlebotomine sandflies (Diptera: Psychodidae) in São Vicente Férrer, a sympatric area to cutaneous and visceral leishmaniasis in the State of Pernambuco, Brazil}

\author{
Flebotomíneos (Diptera: Psychodidae) em São Vicente Férrer, uma área simpátrica para \\ leishmaniose tegumentar e visceral, no Estado de Pernambuco, Brasil
}

\begin{abstract}
Vanessa Cristina Fitipaldi Veloso Guimarães ${ }^{1}$, Pietra Lemos Costa ${ }^{1}$, Fernando José da Silva ${ }^{1}$, Kyldman Thais da Silva ${ }^{1}$, Kamila Gaudêncio da Silva ${ }^{1}$, Ana Isabele Freitas de Araújo ${ }^{1}$, Eduardo Henrique Gomes Rodrigues ${ }^{1}$ and Sinval Pinto Brandão Filho ${ }^{1}$
\end{abstract}

\begin{abstract}
Introduction: In the last decades, a considerable geographic expansion of the leishmaniases in all regions of Brazil has been observed. The present study was carried out to identify the composition of the phlebotomine sandfly fauna and verify the seasonal variation of the main species after environmental changes occurred in São Vicente Férrer Municipality, State of Pernambuco, Brazil. Methods: Captures were carried out during four consecutive nights of each month using Centers for Disease Control and Prevention light traps from September 2009 to September 2010. The correlation between the number of phlebotomine sandflies captured and climatic factors (temperature and rainfall) was evaluated. Results: A total of 13,872 specimens belonging to 20 species were captured, of which, 6,247 (45\%) were females, and 7,625 (55\%) were males. Lutzomyia migonei was the most abundant species with 9,964 $(71.8 \%)$ specimens, being predominant in the intradomicile and peridomicile areas with 108 (86.4\%) and 9,746 (97\%), respectively. In the forest remnants, Lutzomyia complexa 2,395 (65\%) and Lutzomyia sordellii $770(20.8 \%)$ predominated. The correlation analysis between the total number of sandflies captured and climatic factors did not show a significant influence on population density. Conclusions: The high abundance of Lutzomyia migonei and Lutzomyia complexa indicates the possibility of new cases of cutaneous leishmaniasis (CL).
\end{abstract}

Keywords: Leishmaniases. Sandflies. São Vicente Férrer.

\section{RESUMO}

Introdução: Nas últimas décadas tem se observado uma considerável expansão geográfica das leishmanioses em todas as regiões do Brasil. O presente estudo foi realizado para identificar a fauna de flebotomíneos e verificar a sazonalidade das principais espécies após mudanças ambientais ocorridas no município de São Vicente Férrer, Estado de Pernambuco, Brasil. Métodos: As capturas foram realizadas durante quatro noites consecutivas por mês usando armadilhas luminosas CDC, no período de setembro de 2009 a setembro de 2010. A correlação entre o número de flebotomíneos capturados e fatores climáticos (temperatura e umidade) foi avaliada. Resultados: Foi capturado um total de 13.872 espécimes pertencentes a 20 espécies, sendo 6.247 (45\%) fêmeas e 7.625 (55\%) machos. Lutzomyia migonei foi a espécie mais abundante com 9.964 (71,8\%) espécimes, sendo predominante no intradomicílio 108 (86,4\%) e peridomicílio 9.746 (97\%). Nos resquícios de mata primária, predominaram Lutzomyia complexa 2.395 (65\%) e Lutzomyia sordellii 770 (20,8\%). A análise de correlação entre o número total de flebotomíneos capturados e os fatores climáticos não mostrou uma influência significativa na densidade da população. Conclusões: A elevada abundância de Lutzomyia migonei e Lutzomyia complexa indica a possibilidade de novos casos de leishmaniose cutânea (LC).

Palavras-chaves: Leishmanioses. Flebotomíneos. São Vicente Férrer.

1. Centro de Pesquisas Aggeu Magalhães, Fundação Oswaldo Cruz, Recife, PE.

Address to: Dr. Sinval Pinto Brandão Filho. CPqAM/FIOCRUZ. Caixa Postal 7472. Av. Moraes Rego s/n, 50670-420 Recife, PE, Brasil.

Phone: 5581 2101-2562

e-mail: sinval@cpqam.fiocruz.br

Received in 09/08/2011

Accepted in 30/09/2011

\section{INTRODUCTION}

The leishmaniases are diseases caused by Leishmania protozoans that are considered by the World Health Organization as one of most important group of neglected tropical diseases worldwide ${ }^{1}$. There are two main clinical forms of leishmaniasis: cutaneous leishmaniasis (CL) and visceral leishmaniasis (VL). The importance of these diseases for public health is due not only to their high incidence and prevalence but also to their widespread geographical distribution and the possibility of developing severe forms, with significant mortality rates in untreated patients with VL and high morbidity in cases of $\mathrm{CL}^{2}$.

Because of environmental changes resulting from deforestation and urbanization processes, the leishmaniases have significantly increased their importance in public health ${ }^{3,4}$. These environmental changes observed in several areas of Brazil have allowed some sylvatic phlebotomine sandfly species to establish in human dwellings and animal shelters around houses, demonstrating their process of adaptation to the anthropic environment ${ }^{5}$.

In the State of Pernambuco, an increase in the number of cases of leishmaniases has been recorded in all regions of the state, where a progressive expansion was observed in the last 20 years $^{6}$. In the rainforest zone (Zona da Mata), the infection caused by Leishmania (Viannia) braziliensis is the predominant form of the disease ${ }^{7}$. Cases of VL are concentrated in the cities of the semiarid region (Sertão). However, since the 1990s, there has been a dissemination of the disease to the middle scrub (Agreste), and rainforest zone has been recorded, as determined by the increased number of cases reported $^{8}$. São Vicente Férrer records autochthonous cases of both forms of leishmaniases, including reported cases of canine VL9 . Between 1999 and 
2010, 157 autochthonous cases of CL and 15 cases of VL were reported in this area, being considered as an endemic area for CL and a sporadic transmission area for VL form of the disease.

In this context, the present study was carried out to determine the composition of the phlebotomine sandfly fauna in different environments and verify the seasonal variation of the main species after environmental changes occurred in the study area.

\section{METHODS}

\section{Study area}

São Vicente Férrer ( $07^{\circ} 35^{\prime} 28^{\prime \prime} \mathrm{W}, 35^{\circ} 29^{\prime}$ 29"S, and 419m above sea level) is located in the northern rainforest area of Pernambuco, $130.5 \mathrm{~km}$ away from Recife, the state's capital. It has an area of $110,489 \mathrm{~km}^{2}$ and a resident population of 16,598 inhabitants, and the climate is tropical, with a mean average annual temperature of $23^{\circ} \mathrm{C}$. The entomological survey was conducted in Mundo Novo, a rural community where the incidence of both forms of the disease is observed, as well as an intense process of deforestation. In the area, the primary vegetation has largely been substituted by banana tree plantation, and human dwellings and animal shelters (chicken house and stables) are in proximity to remnants of Atlantic rainforest.

\section{Sandfly captures}

Phlebotomine sandflies were captured from September 2009 to September 2010 with Centers for Disease Control and Prevention (CDC) light traps, from 6pm to 6am, during four consecutive nights of each month, distributed in the intradomicile and peridomicile (chicken house and stables) and forest remnants. The number of
CDC light traps ranged from 20 to 51 . The density of phlebotomine sandflies was calculated based on the number of specimens caught per hour of capture (number of traps used per month $\times 12 \mathrm{~h}$ ).

The specimens captured were brought to the laboratory for taxonomic identification according to Young and Duncan ${ }^{10}$.

\section{Climatic data}

The daily climate data (temperature and rainfall) were provided by the Instituto de Tecnologia de Pernambuco. Average monthly values were used in our study.

\section{Statistical analysis}

Male/female ratio and distribution of sandflies in the studied environments were analyzed using chi-square $\left(\chi^{2}\right)$ test. Spearman $(r s)$ correlation coefficient was used to assess the relationship between the number of sandflies captured and climate variables (temperature and rainfall; mean recorded during 10 days preceding the fourth night of capture of each month). Statistical analyses were performed using the R 2.10.0 and BioEstat 5.0 programs. A p $<0.05$ was considered statistically significant.

\section{RESULTS}

A total of 13,872 phlebotomine sandflies belonging to 20 species were captured, of which, 7,625 (55\%) were males, and 6,247 (45\%) were females. The number of males was statistically higher than of females $\left(\chi^{2}=2,733.75, \mathrm{df}=1, \mathrm{p}<0.0001\right)$. Lutzomyia migonei was the predominant species with $9,964(71.8 \%)$ specimens, followed by L. complexa with 2,447 (17.6\%) specimens and L. sordellii with 848 (6.1\%). Other species represented less than $1 \%$ of the captures (Table 1).

TABLE 1 - Distribution of phlebotomine sandflies species by sex and capture sites in Mundo Novo, São Vicente Férrer Municipality, State of Pernambuco, Brazil, from September 2009 to September 2010.

\begin{tabular}{|c|c|c|c|c|c|c|c|c|c|c|c|c|c|c|c|c|}
\hline \multirow[b]{2}{*}{ Species } & \multicolumn{4}{|c|}{ Intradomicile } & \multicolumn{4}{|c|}{ Peridomicile } & \multicolumn{4}{|c|}{ Forest remnants } & \multicolumn{4}{|c|}{ Total } \\
\hline & 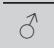 & $q$ & $\mathrm{n}$ & $\%$ & $\hat{\sigma}$ & o & $\mathrm{n}$ & $\%$ & o & 우 & $\mathrm{n}$ & $\%$ & $\delta$ & q & $\mathrm{n}$ & $\%$ \\
\hline L. migonei & 56 & 52 & 108 & 86.4 & 6,250 & 3,496 & 9,746 & 97.0 & 62 & 48 & 110 & 3.0 & 6,368 & 3,596 & 9,964 & 71.8 \\
\hline L. complexa & 3 & 0 & 3 & 2.4 & 3 & 46 & 49 & 0.5 & 699 & 1,696 & 2,395 & 65.0 & 705 & 1742 & 2447 & 17.6 \\
\hline L. sordellii & 1 & 2 & 3 & 2.4 & 37 & 38 & 75 & 0.7 & 258 & 512 & 770 & 20.8 & 296 & 552 & 848 & 6.1 \\
\hline L. evandroi & 11 & 0 & 11 & 8.8 & 47 & 50 & 97 & 0.96 & 7 & 3 & 10 & 0.3 & 65 & 53 & 118 & 0.9 \\
\hline L. typynambai & 0 & 0 & 0 & 0.0 & 0 & 1 & 1 & $<0.01$ & 4 & 76 & 80 & 2.2 & 4 & 77 & 81 & 0.6 \\
\hline L. shannoni & 0 & 0 & 0 & 0.0 & 3 & 2 & 5 & 0.05 & 26 & 32 & 58 & 1.6 & 29 & 34 & 63 & 0.5 \\
\hline L. capixaba & 0 & 0 & 0 & 0.0 & 0 & 1 & 1 & $<0.01$ & 24 & 31 & 55 & 1.5 & 24 & 32 & 56 & 0.4 \\
\hline L. walkeri & 0 & 0 & 0 & 0.0 & 0 & 0 & 0 & 0.0 & 19 & 30 & 49 & 1.3 & 19 & 30 & 49 & 0.4 \\
\hline L. ayrozai & 0 & 0 & 0 & 0.0 & 0 & 0 & 0 & 0.0 & 16 & 28 & 44 & 1.2 & 16 & 28 & 44 & 0.3 \\
\hline L. whitmani & 0 & 0 & 0 & 0.0 & 22 & 11 & 33 & 0.3 & 0 & 0 & 0 & 0.0 & 22 & 11 & 33 & 0.2 \\
\hline L. choti & 0 & 0 & 0 & 0.0 & 0 & 0 & 0 & 0.0 & 0 & 15 & 15 & 0.4 & 0 & 15 & 15 & 0.1 \\
\hline L. furcata & 0 & 0 & 0 & 0.0 & 0 & 0 & 0 & 0.0 & 4 & 8 & 12 & 0.3 & 4 & 8 & 12 & 0.9 \\
\hline L. fischeri & 0 & 0 & 0 & 0.0 & 0 & 0 & 0 & 0.0 & 5 & 0 & 5 & 0.13 & 5 & 0 & 5 & 0.03 \\
\hline L. brasiliensis & 0 & 0 & 0 & 0.0 & 2 & 2 & 4 & 0.03 & 1 & 0 & 1 & 0.02 & 3 & 2 & 5 & 0.03 \\
\hline L. viannamartinsi & 0 & 0 & 0 & 0.0 & 0 & 0 & 0 & 0.0 & 2 & 1 & 3 & 0.08 & 2 & 1 & 3 & 0.02 \\
\hline L. abonnenci & 0 & 0 & 0 & 0.0 & 0 & 0 & 0 & 0.0 & 1 & 1 & 2 & 0.05 & 1 & 1 & 2 & 0.01 \\
\hline L. goiana & 0 & 0 & 0 & 0.0 & 0 & 0 & 0 & 0.0 & 0 & 1 & 1 & 0.02 & 0 & 1 & 1 & $<0.01$ \\
\hline L. oswaldoi & 0 & 0 & 0 & 0.0 & 0 & 0 & 0 & 0.0 & 0 & 1 & 1 & 0.02 & 0 & 1 & 1 & $<0.01$ \\
\hline Total & 65 & 60 & 125 & 100.0 & 6,393 & 3,664 & 10,057 & 100.0 & 1,161 & 2,529 & 3,690 & 100.0 & 7,625 & 6,247 & 13,872 & 100.0 \\
\hline
\end{tabular}


The insects showed preference for the peridomestic environment with $10,057(72.5 \%)$ specimens, followed by the forest remnants with $3,690(26.6 \%)$ and $125(0.9 \%)$ in the intradomicile $\left(\chi^{2}=16,424.37, \mathrm{df}=2, \mathrm{p}<0.0001\right)$. L. migonei was predominant in the intradomicile and peridomicile ( $86.4 \%$ and $97 \%$, respectively). In forest remnants, the most frequent species were L. complexa (65\%) and L. sordellii (20.8\%), whereas other species represented $14.2 \%$ for the specimens captured.

Lutzomyia migonei, L. complexa, L. sordellii, and L.evandroi were the only species captured in all sites. An interesting aspect was the presence of L. complexa, L. naftalekatzi, L. tupynambai, L. shannoni, L. braziliensis, and L. capixaba in the peridomestic environment.

Considering the monthly distribution of phlebotomine sandflies (Figure 1), three peaks in the population density of L. migonei were observed in February, May, and September 2010, this species being the only one captured in all months. Lutzomyia complexa had the highest density in March 2010 and L. sordellii in April 2010. The density of these species during the year showed some similarities, as in October 2009 and July 2010, and high divergence from January to May 2010, when an alternated distribution pattern was observed.

During the study period, a mean monthly temperature of $26.1^{\circ} \mathrm{C}$ (range, 23.3 to $28.3^{\circ} \mathrm{C}$ ) and rainfall of $98.5 \mathrm{~mm}^{3}$ (range, 6.6 to $417.6 \mathrm{~mm}^{3}$ ) were recorded (Figure 2). The occurrence of a greater number of phlebotomine sandflies, mainly L. migonei, coincided with the periods before and after the raining period. However, no correlation was found between the monthly number of sandflies captured and mean temperature $(\mathrm{rs}=0.1592, \mathrm{p}=0.6034)$ or rainfall $(\mathrm{rs}=0.1768, \mathrm{p}=0.5634)$ (Figure 3$)$.

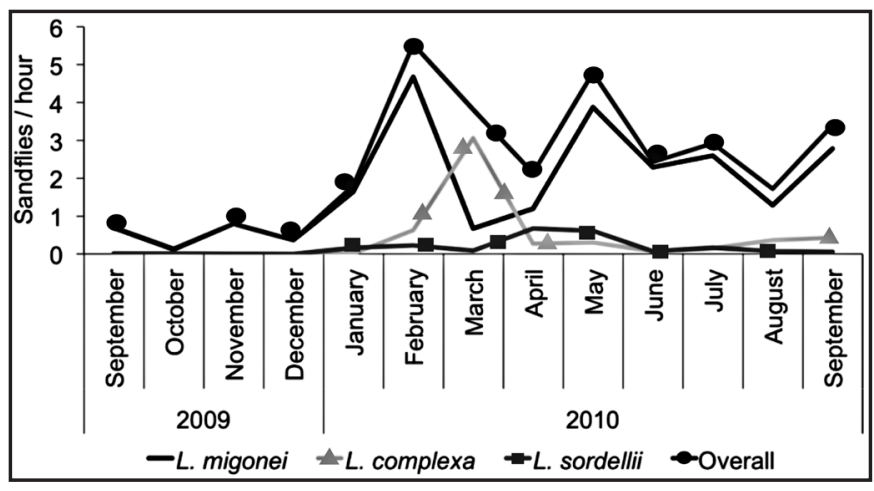

FIGURE 1 - Monthly distribution of phlebotomine sandfly species per hour of capture in Mundo Novo, São Vicente Férrer Municipality, State of Pernambuco, Brazil, from September 2009 to September to 2010.

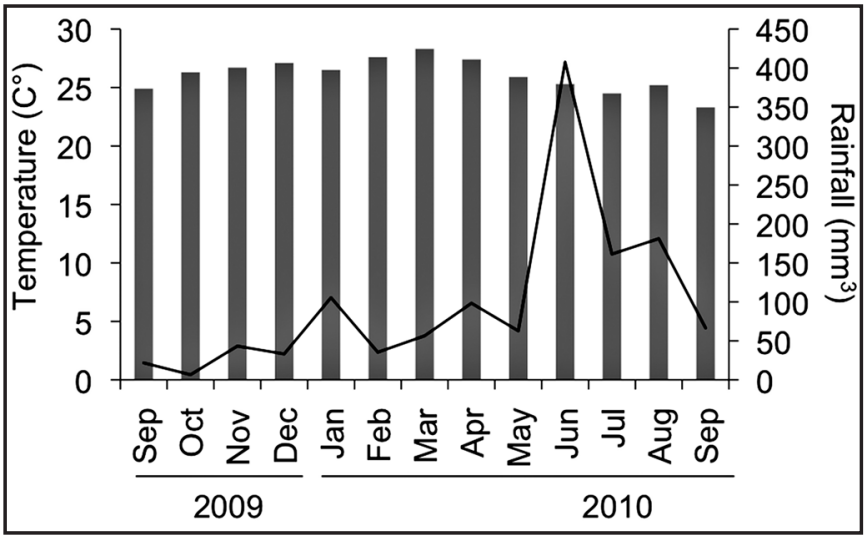

FIGURE 2 - Monthly averages for climate variables (temperature and rainfall) in Mundo Novo, São Vicente Férrer Municipality, State of Pernambuco, Brazil, from September 2009 to September 2010.

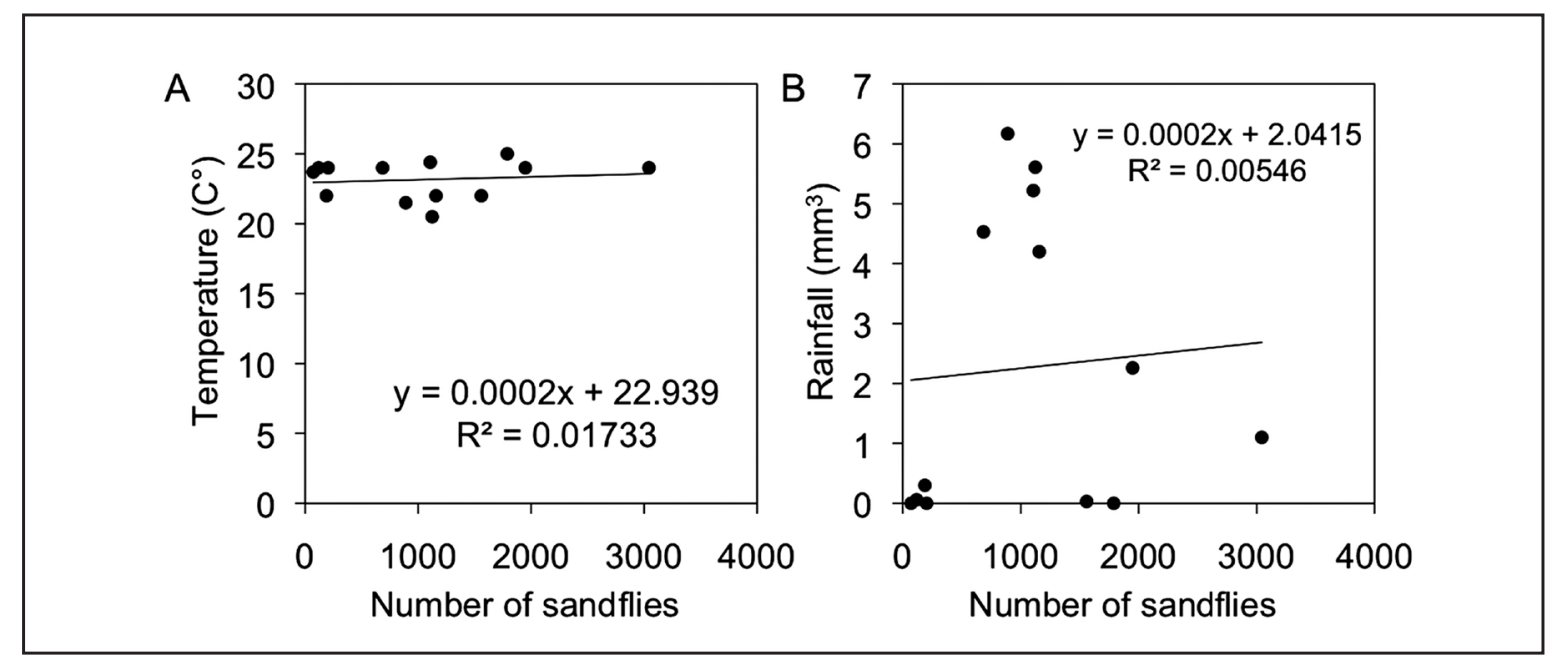

FIGURE 3 - Correlation analysis between population density of phlebotomine sandfly species and temperature (A) and rainfall (B) in Mundo Novo, São Vicente Férrer Municipality, State of Pernambuco, Brazil, from September 2009 to September 2010.

\section{DISCUSSION}

The diversity of the phlebotomine sandfly fauna of São Vicente Férrer has previously been reported ${ }^{6}$. However, a relevant point in this study is the change in the diversity of the fauna and distribution of some species in the same collection sites after 7 years. The preliminary study in $2002^{6}$ showed the occurrence of 17 species. In the current study, 20 species were observed, including the first report of
L. ayrozai, L. goiana, and L. viannamartinsi in this area. It also was worthy of note the presence of L. shannoni, L. naftalekatzi, L. tupynambai, L. brasiliensis, and L. capixaba in the peridomestic environment, which was not previously reported. Although captured sporadically, the presence of these species reflects the result of environmental changes that occurred in this area, such as intense deforestation associated with the absence of sanitary conditions in the animal shelters localized in the peridomestic environment, contributing to the possible domiciliation of these species. 
The greater abundance and diversity of phlebotomine sandflies in the peridomicile has been observed in several areas of Brazil ${ }^{11-14}$. This behavior increases the risk of transmission of the leishmaniases, and it is related to the presence of animals in household surroundings, as well as vegetation and soil type, which might favor the establishment of breeding sites for phlebotomine sandflies ${ }^{15}$.

The predominance of L. migonei often has been reported in the area of CL associated with Leishmania (Viannia) braziliensis ${ }^{16,17}$. The abundance of this species in the intradomicile and peridomicile, as well as the constant presence during the study, reveals their adaptation to the anthropic environment. This behavior also has been observed in several Brazilian States, such as in São Paulo ${ }^{18}$, Paraná ${ }^{19}$, and Minas Gerais ${ }^{20}$. Aguiar et al. ${ }^{21}$ highlighted the high anthropophily of L. migonei, its adaptability to modified environments, and its low occurrence in wild environments, which also was observed in the study area. Moreover, the vector role of $L$. migonei has been suggested in areas of autochthonous cases of VL where L. longipalpis, the classic

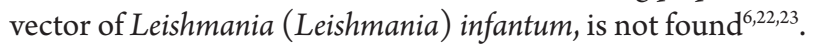

Lutzomyia complexa, the predominant species in forest remnants, which presents considerable distribution in Pernambuco, also has been reported in Recife, Paudalho (northern rainforest area) and Amaraji (southern rainforest area) ${ }^{24}$. The current study corroborates the data presented by Brandão-Filho et al. ${ }^{25}$ that reported the preference of this species for forested environments and its relationship with the enzootic cycle of CL. Lutzomyia complexa also has an extensive geographical distribution in the Amazon region, in the State of Pará and the south Amazon River, including the Marajó island, where is incriminated in the transmission of Leishmania (Viannia) braziliensis ${ }^{26}$, being highly anthropophilic, preferentially biting human rather than dogs or chickens ${ }^{27}$.

Lutzomyia sordellii, the third most frequent species in the study area, is recorded in all regions of the country ${ }^{28}$, being reported in peridomestic environments, such as animal shelters (e.g., chicken, pig pens, and corrals), houses, tree trunks, and caves in different areas of Brazil $^{6,29,30}$, but so far, there is no consistent data on its participation in the transmission of CL.

The seasonal pattern of the phlebotomine sandfly fauna showed an irregular distribution, where the increase in population density occurred before or after the rainy period. A similar finding was presented by Gomes ${ }^{31}$ during the study of a population of L. umbratilis in the Amazon region. Nonetheless, other authors have observed high occurrence of these sandflies also during rainy month $\mathrm{s}^{29,32}$.

According to Ximenes et $\mathrm{al}^{33}$, the pattern of seasonal variation of phlebotomine sandflies is influenced by several abiotic factors, depending on ecology of species and the geographical peculiarities of the area in which the study is conducted. Thus, because of variation in climatic factors over time, the same species may have different seasonal patterns in the same geographical area.

The lack of correlation between the total number of specimens captured and climatic variables showed that the temperature and rainfall did not affect the sandfly population, as observed by Dias et al. ${ }^{34}$ and Souza et al. ${ }^{35}$ in the State of Minas Gerais, Brazil, and Missawa and Dias ${ }^{12}$ in the State of Mato Grosso, Brazil. Nevertheless, other studies have revealed a significant correlation between the number of phlebotomine sandflies, rainfall, and humidity ${ }^{32,36}$ which favors vegetation growth and accumulation of organic matter in the soil, allowing the emergence of breeding sites ${ }^{34}$.

Studies about the distribution of phlebotomine sandfly species are important to identify areas of active leishmaniases transmission that might in turn be related to a particular environment. In this sense, data here presented can support monitoring and surveillance programs and the establishment of effective control measures against the leishmaniases in São Vicente Férrer.

\section{CONFLICT OF INTEREST}

The authors declare that there is no conflict of interest.

\section{FINANCIAL SUPPORT}

This research was supported by Fundação de Amparo à Ciência e Tecnologia do Estado de Pernambuco (FACEPE), APQ-0630-2.13/08.

\section{REFERENCES}

1. World Health Organization. First WHO report on neglected tropical diseases 2010: working to overcome the global impact of neglected tropical diseases. $1^{\text {st }}$ ed. Switzerland: WHO; 2010.

2. Gontijo B, Carvalho MLR. Leishmaniose tegumentar americana. Rev Soc Bras Med Trop 2003; 36:71-80.

3. Shaw JJ. The leishmaniases - survival and expansion in a changing world. Mem Inst Oswaldo Cruz 2007; 102:541-547.

4. Luz ZMP, Pimenta DN, Cabral ALV, Fiúza VOP, Rabello AA. A urbanização das leishmanioses e a baixa resolutividade diagnóstica em municípios da Região Metropolitana de Belo Horizonte. Rev Soc Bras Med Trop $2001 ; 34: 249-254$.

5. Dujardin JC. Risk factors in the spread of leishmaniases: towards integrated monitoring? Trends Parasitol 2006; 22:4-6.

6. Carvalho MR, Lima BS, Marinho-Júnior JF, Silva FJ, Valença HF, Almeida FA, et al Phlebotomine sandfly species from an American visceral leishmaniasis area in the Northern Rainforest region of Pernambuco State, Brazil. Cad Saude Publica 2007; 23:1227-1232.

7. Brandão-Filho SP, Brito MEF, Carvalho FG, Ishikawa EA, Cupolillo E, Floeter-Winter L, et al. Wild and synanthropic hosts of Leishmania (Viannia) braziliensis in the endemic cutaneous leishmaniasis locality of Amaraji, Pernambuco State, Brazil. Trans R Soc Trop Med Hyg 2003; 97:291-296.

8. Dantas-Torres F, Brandão-Filho S. Expansão geográfica da leishmaniose visceral no Estado de Pernambuco. Rev Soc Bras Med Trop 2006; 39:352-356.

9. Dantas-Torres F, Paiva-Cavalcanti M, Figueiredo LA, Melo MF, Silva FJ, Silva AL, et al. Cutaneous and visceral leishmaniosis in dogs from a rural community in northeastern Brazil. Vet Parasitol 2010; 170:313-317.

10. Young D, Duncan M. Guide to the identification and geographic distribution of Lutzomyia sand flies in Mexico, the West Indies, Central and South America (Diptera: Psychodidae). Mem Am Entomol Inst 1994; 54:1-881.

11. Barata RA, França-Silva JC, Mayrink W, Silva JC, Prata A, Lorora ES, et al Aspectos da ecologia e do comportamento de flebotomíneos em área endêmica de leishmaniose visceral, Minas Gerais. Rev Soc Bras Med Trop 2005; 38:421-425.

12. Missawa NA, Dias ES. Phlebotomine sand flies (Diptera: Psychodidae) in the municipality of Várzea Grande: an area of transmission of visceral leishmaniasis in the state of Mato Grosso, Brazil. Mem Inst Oswaldo Cruz 2007; 102:913-918.

13. Barata RA, Paz GF, Bastos MC, Andrade RCO, Barros DCM, Silva FOL, et al. Phlebotomine sand flies (Diptera: Psychodidae) in Governador Valadares, a transmission área for American tegumentar leishmaniasis in State of Minas Gerais, Brazil. Rev Soc Bras Med Trop 2011; 44:136-139.

14. Silva FS, Carvalho LPC, Cardozo FP, Moraes JLP, Rebêlo JMM. Sand Flies (Diptera: Psychodidae) in a Cerrado Area of the Maranhão State, Brazil. Neotrop Entomol 2010; 39:1032-1038.

15. Camargo-Neves VLF, Katz G, Rodas LAC, Poletto DW, Spínola RMF, Cruz OG Utilização de ferramentas de análise espacial da vigilância epidemiológica de leishmaniose visceral americana - Araçatuba, São Paulo, Brasil, 1998-1999. Cad Saude Publica 2001; 17:1263-1267. 
16. Andrade-Filho JD, Brazil RP. Phlebotomine sand flies (Diptera: Psychodidae: Phlebotominae) of Alagoas State, Northeast of Brazil. Neotrop Entomol 2009; 38:688-690

17. Silva AC, Grunewald J. Contribution to the sand fly fauna (Diptera: Phlebotomine) of Rio Grande do Sul, Brazil and Leishmania (Viannia) infections. Mem Inst Oswaldo Cruz 1999; 94:579-582.

18. Camargo-Neves VLF, Gomes AC, Poletto DW, Antunes JLF. Correlação da presença de espécies de flebotomíneos (Diptera: Psychodidae) com registros de casos da leishmaniose tegumentar americana no Estado de São Paulo, Brasil. Rev Soc Bras Med Trop 2002; 35:299-306.

19. Massafera R, Silva AM, Carvalho AP, Santos DR, Galati EAB, Teodoro U. Fauna de flebotomíneos do município de Bandeirantes, no estado do Paraná. Rev Saude Publica 2005; 39:571-577.

20. Saraiva L, Lopes JS, Oliveira GBM, Batista FA, Falcão AL, Andrade-Filho JD. Estudo dos flebotomíneos (Diptera: Psychodidae) em área de leishmaniose tegumentar americana nos municípios de Alto Caparaó e Caparaó, Estado de Minas Gerais. Rev Soc Bras Med Trop 2006; 39:56-63.

21. Aguiar GM, Vilela ML, Lima RB. Ecology of the sandflies of Itaguaí, an area of cutaneous leishmaniasis in State of Rio de Janeiro. Food preferences (Diptera, Psychodidae, Phlebotominae). Mem Inst Oswaldo Cruz 1987; 82:583-584.

22. Carvalho MR, Valença HF, Silva FJ, Pita-Pereira D, Pereira TA, Britto C, et al. Natural Leishmania infantum infection in Migonemyia migonei (França, 1920) (Diptera: Psychodidae: Phlebotominae) the putative vector of visceral leishmaniasis in Pernambuco State, Brazil. Acta Trop 2010; 116:108-110.

23. Souza MB, Marzochi MCA, Carvalho RW, Ribeiro PC, Pontes CS, Caetano JM, et al. Ausência de Lutzomyia longipalpis em algumas áreas de ocorrência de leishmaniose visceral no município do Rio de Janeiro. Cad Saude Publica 2003; 19:109-118.

24. Dantas-Torres F, Andrade AJ, Tenório KER, Andrade-Filho JD, Balbino VQ Brandão-Filho SP. Phlebotomine sand flies (Diptera: Psychodidae: Phlebotominae) in the State of Pernambuco. Rev Soc Bras Med Trop 2010; 43:733-736

25. Brandão-Filho SP, Brito MEF, Martins CAP, Sommer IB, Valença HF, Almeida FA, et al. Leishmaniose tegumentar americana em centro de treinamento militar localizado na Zona da Mata de Pernambuco, Brasil. Rev Soc Bras Med Trop 1998; 3:575-578

26. Souza A, Ishikawa E, Braga R, Silveira F, Lainson R, Shaw J. Psychodopygus complexus, a new vector of Leishmania braziliensis to humanas in Pará State, Brazil. Trans R Soc Trop Med Hyg 1996; 90:112-113.

27. Campbell-Lendrum DH, Pinto MC, Brandão-Filho SP, Souza AA, Ready PD, Davies CR. Experimental comparison of anthropophily between geographically dispersed populations of Lutzomyia whitmani (Diptera: Psychodidae). Med Vet Entomol 1999; 13:299-309.

28. Rangel EF, Lainson R. Flebotomíneos do Brasil. $1^{\text {st }}$ ed. Rio de Janeiro. Fundação Oswaldo Cruz; 2003.

29. Galati EAB, Nunes VLB, Rego Jr FA, Oshiro ET, Chang MR. Estudo de flebotomíneos (Diptera, Psychodidae) em foco de leishmaniose visceral no Estado de Mato Grosso do Sul, Brasil. Rev Saude Publica 1997; 31:378-390.

30. Brandão-Filho SP, Donalisio MR, Silva FJ, Valença HF, Costa PL, Shaw JJ, et al. Spatial and temporal patterns of occurrence of Lutzomyia sand fly species in an endemic area for cutaneous leishmaniasis in the Atlantic Forest region of northeast Brazil. J Vector Ecol 2011; 36:71-76.

31. Gomes LHM. Variação mensal e infecção em Lutzomyia umbratilis Ward \& Fraiha 1977, Lutzomyia anduzei Rozeboom 1942, Lutzomyia flaviscutellata Mangabeira 1942 e Lutzomyia olmeca nociva Young \& Arias 1982 (Diptera: Psychodidae) por tripanosomatídeos (Kinetoplastida: Trypanosomatidae) em áreas de treinamento militar na Amazônia. [Dissertation]. [Manaus]: Universidade Federal do Amazonas; 2003. 101 p.

32. Barata RA, França-Silva JC, Fostes-Dias CL, Costa RT, Silva JC, Vieira EP, et al. Phlebotomines sand flies in Porteirinha, an endemic area of American visceral leishmaniasis transmission in the State of Minas Gerais, Brazil. Mem Inst Oswaldo Cruz 2004; 99:481-487.

33. Ximenes MFFM, Castellón EG, Souza MF, Menezes AAL, Queiroz JM, Silva VPM, et al. Effect of abiotic factors on seasonal population dynamics of Lutzomyia longipalpis (Diptera: Psychodidae) in Northeastern Brazil. J Med Entomol 2006; 43:990-995.
34. Dias ES, França-Silva JC, Silva JC, Monteiro EM, Paula KM, Gonçalves CM, et al. Flebotomíneos (Diptera: Psychodidae) de um foco de leishmaniose tegumentar no Estado de Minas Gerais. Rev Soc Bras Med Trop 2007; 40: 49-52.

35. Souza CM, Pessanha JE, Barata RA, Monteiro EM, Costa DC, Dias ES. Study on phlebotomine sand fly (Diptera: Psychodidae) fauna in Belo Horizonte, State of Minas Gerais, Brazil. Mem Inst Oswaldo Cruz 2004; 99:795-803.

36. Monteiro EM, França-Silva JC, Costa RT, Costa DC, Barata RA, Paula EV, et al. Leishmaniose visceral: estudo de flebotomíneos e infecção canina em Montes Claros, Minas Gerais. Rev Soc Bras Med Trop 2005; 38:147-152. 